\title{
Accuracy of stone casts obtained by different impression materials
}

\section{Adriana Cláudia Lapria Faria ${ }^{(a)}$ Renata Cristina Silveira Rodrigues $^{(b)}$ \\ Ana Paula Macedo(c) \\ Maria da Gloria Chiarello de Mattos $^{(d)}$ \\ Ricardo Faria Ribeiro(d)}

(a)DDS, MS; (b)DDS, PhD, Assistant Professor of Removable Partial Denture; (c)Electrical Engineer; (d)DDSs, PhDs, Full Professors of Removable Partial Denture - Department of Dental Materials and Prosthodontics, School of Dentistry of Ribeirão Preto, University of São Paulo, Ribeirão Preto, SP, Brazil.
Corresponding author:

Renata Cristina Silveira Rodrigues

Av. do Café, s/n, Monte Alegre

Ribeirão Preto - SP - Brazil

CEP: 14040-904

E-mail:renata@forp.usp.br

Received for publication on Jul 10, 2007

Accepted for publication on Oct 24, 2007
Abstract: Several impression materials are available in the Brazilian marketplace to be used in oral rehabilitation. The aim of this study was to compare the accuracy of different impression materials used for fixed partial dentures following the manufacturers' instructions. A master model representing a partially edentulous mandibular right hemi-arch segment whose teeth were prepared to receive full crowns was used. Custom trays were prepared with auto-polymerizing acrylic resin and impressions were performed with a dental surveyor, standardizing the path of insertion and removal of the tray. Alginate and elastomeric materials were used and stone casts were obtained after the impressions. For the silicones, impression techniques were also compared. To determine the impression materials' accuracy, digital photographs of the master model and of the stone casts were taken and the discrepancies between them were measured. The data were subjected to analysis of variance and Duncan's complementary test. Polyether and addition silicone following the single-phase technique were statistically different from alginate, condensation silicone and addition silicone following the double-mix technique $(\mathrm{p} \leq .05)$, presenting smaller discrepancies. However, condensation silicone was similar $(\mathrm{p} \geq .05)$ to alginate and addition silicone following the double-mix technique, but different from polysulfide. The results led to the conclusion that different impression materials and techniques influenced the stone casts' accuracy in a way that polyether, polysulfide and addition silicone following the single-phase technique were more accurate than the other materials.

Descriptors: Dental impression materials; Dental impression technique; Fixed partial denture. 


\section{Introduction}

Impression taking and pouring are critical steps in the process of producing successful crowns and bridges in oral rehabilitation. Impression materials should reproduce hard and soft tissues around prepared and adjacent teeth in order to obtain biologically, mechanically, functionally and esthetically acceptable restorations. ${ }^{1,2,3}$ There are some factors that affect definitive impression quality such as tooth preparation design, soft tissue management, tray selection, impression material and impression technique. ${ }^{4,5}$

There are several elastic impression materials available for dental use: synthetic elastomeric materials, including polysulfide, condensation silicone, addition silicone and polyether; and hydrocolloids. ${ }^{6,7}$ All these materials are used for reproducing oral conditions in order to construct restorations.

One example of hydrocolloid is alginate, a popular material in the last years because of its easy mixing and low cost when compared to elastomers. Although some professionals have been using alginate in clinical practice for definitive impressions, problems with dimensional stability and unsatisfactory detail reproduction are some of the limitations to its use. ${ }^{8}$

Over time, several materials have been introduced in the marketplace in order to improve impression quality. The first synthetic elastomeric impression material, launched in 1950, was polysulfide. Its elasticity was sufficient for it to be removed from retentive areas. Later, in 1955, the introduction of condensation silicone represented an advance in impressions materials, as it no longer required custom trays. In 1965, polyether was introduced in Germany as the first elastomeric material developed to be used in dentistry, while the others were first used in industry. Addition silicones were launched in 1975 presenting good characteristics. ${ }^{6,7}$

In spite of their different characteristics, all these impression materials are used for reproducing oral tissues. So, the aim of the present study was to compare the accuracy of different materials used in impressions for fixed partial dentures.

\section{Material and Methods}

The impression materials used in the present study and their manufacturer's instructions are presented in Table 1.

A master model was prepared representing a partially edentulous mandibular right hemi-arch segment. The remaining teeth in the hemi-arch segment were the 44 and $46\left(1^{\text {st }}\right.$ premolar and $1^{\text {st }}$ molar). The $45\left(2^{\text {nd }}\right.$ premolar $)$ was missing. The remaining teeth were made in Co-Cr alloy and presented fullcrown preparations (Figure 1). This master model was tightened to the horizontal base of a dental surveyor.

To perform the impressions, custom trays were fabricated with auto-polymerizing acrylic resin and there was a device on these trays to tighten them to the vertical shaft of the dental surveyor. Perfora-

Table 1 - Trademarks, manufacturers and pouring times of the impression materials evaluated.

\begin{tabular}{l|l|l|l}
\hline \multicolumn{1}{c|}{ Material } & Trademark & \multicolumn{1}{|c|}{ Manufacturer } & $\begin{array}{c}\text { Pouring } \\
\text { time* }^{*}\end{array}$ \\
\hline Alginate & Jeltrate & $\begin{array}{l}\text { Dentsply Ind. Com., } \\
\text { Petrópolis, RJ, Brazil }\end{array}$ & Immediate \\
\hline Polysulfide & Coe-flex & $\begin{array}{l}\text { GC America INC., } \\
\text { Alsip, IL, USA }\end{array}$ & Immediate \\
\hline Polyether & Impregum & $\begin{array}{l}\text { 3M ESPE, Seefeld, } \\
\text { Germany }\end{array}$ & 30 minutes \\
\hline $\begin{array}{l}\text { Condensation } \\
\text { silicone }\end{array}$ & Silon & $\begin{array}{l}\text { Dentsply Ind. Com., } \\
\text { Petrópolis, RJ, Brazil }\end{array}$ & Immediate \\
\hline $\begin{array}{l}\text { Addition } \\
\text { silicone }\end{array}$ & Aquasil LV & $\begin{array}{l}\text { Dentsply Ind. Com., } \\
\text { Petrópolis, RJ, Brazil }\end{array}$ & 60 minutes \\
\hline
\end{tabular}

*According to the manufacturers' instructions.

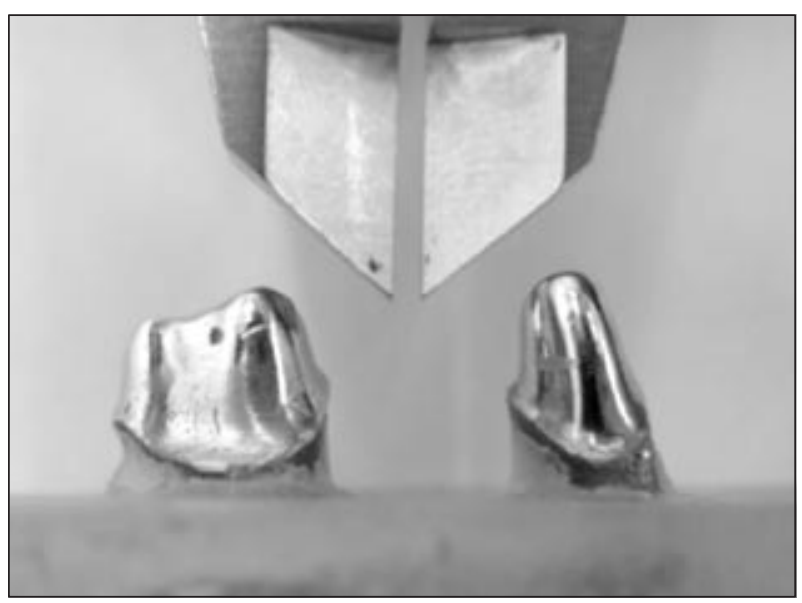

Figure 1 - Master model. 


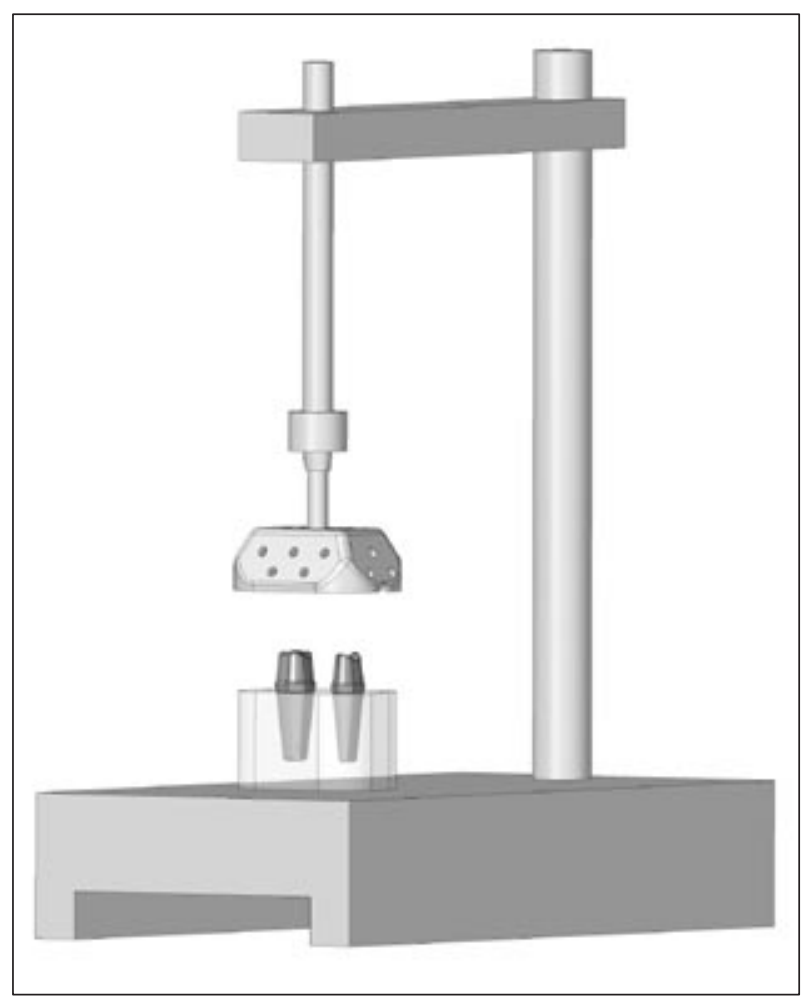

Figure 2 - Master model and perforated tray positioned in the dental surveyor for impressions.

tions in the trays allowed the materials to extravasate without resistance, allowing complete seating of the tray on the master model (Figure 2). For the impressions, each material was mixed according to its manufacturer's instructions. After mixing, the tray and impression syringe were filled and the material was injected over the prepared teeth. Next, the tray was tightened to the dental surveyor and the impression was taken. The use of the dental surveyor allowed the path of insertion and removal of the tray to be standardized. For the silicones, two impression techniques were used: single-phase (SP) and double-mix (DM). When the double-mix technique was performed, the teeth were relieved with wax $(1 \mathrm{~mm})$ for the first impression.

After the setting time, the tray was separated from the master model. According to the manufacturer's instructions, the stone (Durone IV, Dentsply Ind. Com., Petrópolis, RJ, Brazil) was mixed by hand at a powder / water ratio of $100 \mathrm{~g} / 20 \mathrm{ml}$ within 1 minute and the impressions were poured under gentle vibration. For stone cast standardizing,

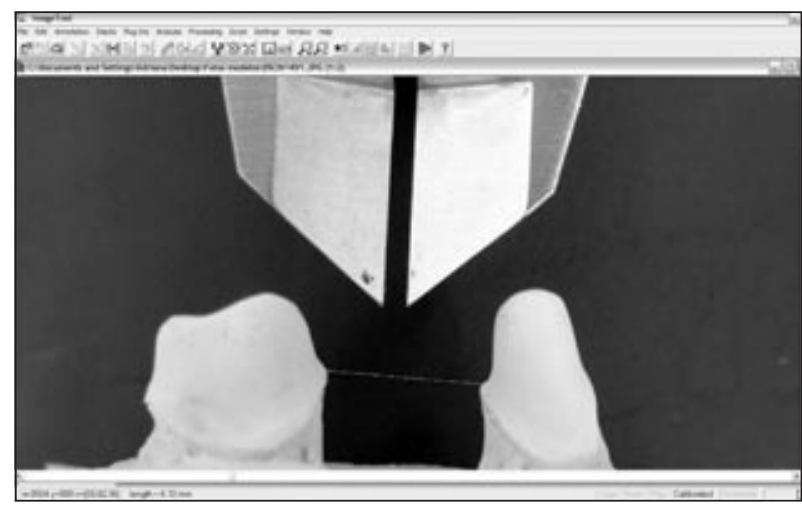

Figure 3 - Measurement between teeth using the software Image Tool.

a device was fabricated to box the tray during the pouring. After $1 \mathrm{~h}$, the stone casts were separated from the impressions.

To determine the impression materials' accuracy, photographs of the master model or stone casts and a caliper (Mitutoyo Sul Americana Ltda., Suzano, SP, Brazil), set at $1 \mathrm{~mm}$, were taken using a digital camera. ${ }^{9}$ After this, the software Image Tool (The University of Texas Health Science Center in San Antonio, TX, USA) was used to measure the distance between the teeth. Calibration was achieved based on the caliper's reference, and the distance between the edges of the tooth preparations was measured. Three measurements were made for each image and the mean of these measurements was used. The discrepancies between the master model and the stone casts were determined by the absolute value of the differences between them (Figure 3).

The number of samples was five for each material. The data were subjected to analysis of variance and Duncan's complementary test to compare the accuracy of the different impression materials using the statistical software SPSS 12.0 for Windows (SPSS Inc., Chicago, IL, USA).

\section{Results}

The mean and standard deviation of the discrepancies between the prepared tooth edges in the master model and in the stone casts are presented in Table 2 and Graph 1.

Statistical analysis showed significant difference $(\mathrm{p} \leq 0.05)$ between the discrepancies between mas- 
Table 2 - Measurement of discrepancies $(\mathrm{mm})$ between the prepared tooth edges in the master model and in the stone casts. The data are shown as means and standard deviations. Different letters indicate statistical difference $(p<.05)$.

\begin{tabular}{c|c|c|c|c|c|c|c}
\hline Materials & Polysulfide & Polyether & $\begin{array}{c}\text { Addition } \\
\text { silicone (SP) }\end{array}$ & $\begin{array}{c}\text { Addition } \\
\text { silicone (DM) }\end{array}$ & $\begin{array}{c}\text { Condensation } \\
\text { silicone (SP) }\end{array}$ & $\begin{array}{c}\text { Condensation } \\
\text { silicone (DM) }\end{array}$ & $\begin{array}{c}\text { Alginate } \\
\text { Mean }\end{array}$ \\
\hline SD & $0.17^{\mathrm{a}, \mathrm{b}}$ & $0.12^{\mathrm{a}}$ & $0.15^{\mathrm{a}}$ & $0.30^{\mathrm{b}, \mathrm{c}}$ & $0.38^{\mathrm{c}}$ & $0.40^{\mathrm{c}}$ & $0.30^{\mathrm{b}, \mathrm{c}}$ \\
\hline
\end{tabular}

SP: single-phase. DM: double-mix.

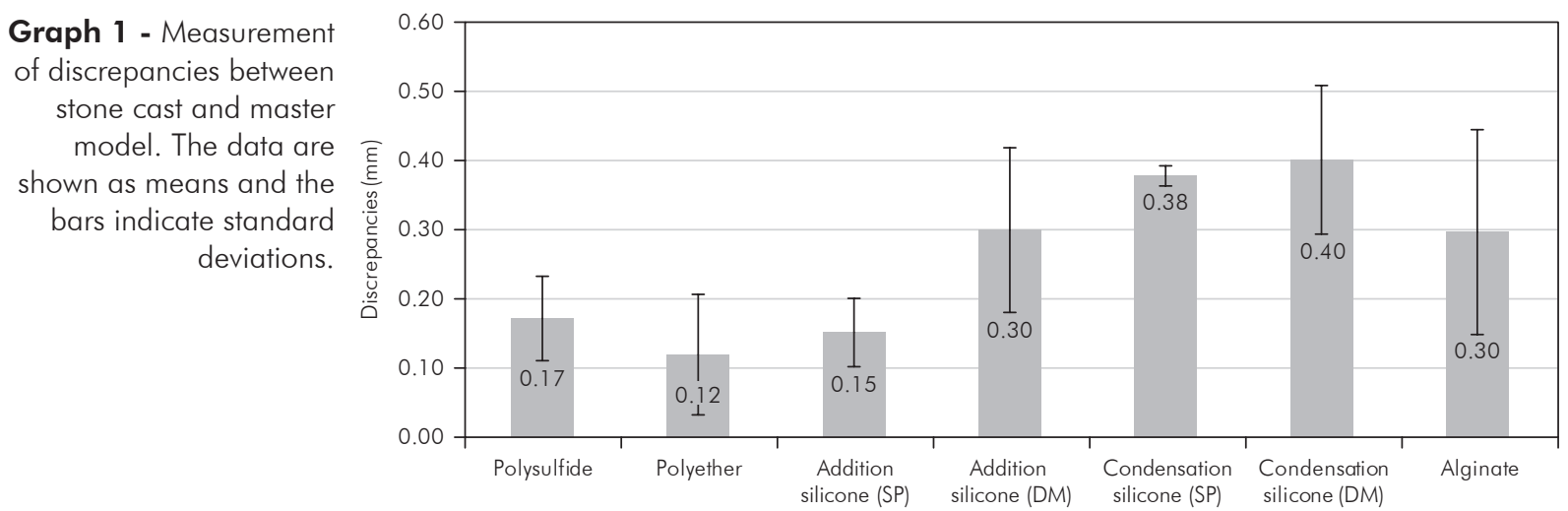

ter model and stone casts obtained by the different impression materials. The data showed that polyether was statistically different from alginate, addition silicone (DM) and condensation silicone (DM and SP), presenting smaller discrepancies. Condensation silicone (DM and SP) was similar $(\mathrm{p}=0.126)$ to alginate and addition silicone (DM), but different from polysulfide and addition silicone (SP). In addition, polysulfide was statistically similar to polyether, addition silicone (SP e DM) and alginate.

\section{Discussion}

An accurate stone cast is indispensable for the fabrication of a crown or bridge and the choice of impression material is vital.

There are specifications for impression materials, according to ANSI/ADA, ${ }^{10,11}$ to test the ability of reproducing dental details; however, these specifications have used simulated tooth models presenting areas that can be easily measured. ${ }^{12}$ Although the test embodied in the specifications provides good baseline data to compare materials, the testing conditions differ from those encountered during clinical practice; therefore, the master model used in the present study represented a partially edentulous mandibular right hemi-arch segment, a common situation in clinical practice.

Among the materials tested in this study, alginate is the most popular in dental clinics because of its low cost and easy use. Studies that compared alginate and elastomeric impression materials have found similar accuracy results. ${ }^{12-14}$ Confirming the results of the studies cited above, in the present study alginate presented an accuracy similar to that of elastomeric impression materials other than polyether, suggesting that alginate can be used to replace some elastomeric impression materials like condensation silicone and addition silicone following the double-mix technique. Alginate's instability through time and its surface roughness because of water loss are disadvantages, limiting its use only for diagnostic casts. ${ }^{9}$ Nevertheless, alginate presented an acceptable accuracy in the present study, as long as the manufacturer's instructions for pouring time are followed.

Polyether and polysulfide are materials whose accuracy is greater. Even though custom trays are required, which increases the clinical time spent for the procedure, the trays provide material economy ${ }^{2}$ and standardize the impression material thickness, improving accuracy and decreasing permanent de- 
formation. ${ }^{15,16}$ Besides, polyether is extremely stiff when set, requiring great forces to remove full-arch impressions. ${ }^{12}$ Henry, Harnist ${ }^{17}$ (1974) reported that polyether was the most accurate impression material, as also found in the present study.

According to $\mathrm{Wee}^{18}$ (2000), the use of either polyether or addition silicone is recommended for direct implant impressions. However, Thongthammachat et al. ${ }^{2}$ (2002) related that addition silicone was clearly superior to polyether although some clinicians have suggested that polyether presents superior elastic properties and accuracy for implant reconstruction.

As silicones are available in the marketplace as putty and light body material, they do not require the use of custom trays. While condensation silicone presents ethylic alcohol as a product of the reaction, causing shrinkage of the impression, in the addition silicone reaction volatile products are not released, improving accuracy. ${ }^{6}$ However, addition silicones are intrinsically hydrophobic in nature, which can result in voids at the tooth preparation's margin in the impression and bubbles in the gypsum casts. Therefore, recently, addition silicones have been labeled as hydrophilic due to extrinsic surfactant addition, improving oral tissue and gypsum wettability when the impression and cast pouring are performed. ${ }^{6,19}$ Even though a superficial characteristics evaluation was not the aim of the present study, bubbles or voids were not observed on the stone cast surfaces obtained with addition silicone. In relation to accuracy, condensation silicones presented greater discrepancies than did addition silicones.

\section{References}

1. Perakis N, Belser UC, Magne P. Final impressions: a review of material properties and description of a current technique. Int J Periodontics Restorative Dent. 2004;24(2):109-17.

2. Thongthammachat S, Moore BK, Barco MT 2 ${ }^{\text {nd }}$, Hovijitra S, Brown DT, Andres CJ. Dimensional accuracy of dental casts: influence of tray material, impression material, and time. J Prosthodont. 2002;11(2):98-108.

3. Tjan AH, Whang SB, Tjan AH, Sarkissian R. Clinically oriented evaluation of the accuracy of commonly used impression materials. J Prosthet Dent. 1986;56(1):4-8.

4. Kugel G, Swift EJ Jr, Sorensen JA, Tucker JH, Dunne JT Jr. A prospective clinical evaluation of electronically mixed polyvi-
On the other hand, differences were observed between the impression techniques when addition silicone was used. The single-phase technique presented greater accuracy than the double-mix technique. These results confirm the results found by Hung et al. ${ }^{20}$ (1992), who compared the one-step versus the two-step putty wash addition silicone impression technique and found that the one-step was more accurate than the two-step technique.

The discrepancies between stone casts and master model had positive and negative values, but in order to avoid false results due to the positive and negative values canceling each other out, the data were converted to absolute values, as also did Chen et al. ${ }^{9}$ (2004). Based on the present methodology, which defined accuracy as a consistency in the measurements of the distance between two determined points on the abutment teeth, it was not possible to suggest the existence of shrinkage or expansion of the stone casts due to the fact that some areas present shrinkage due to polymerization shrinkage towards the center of the material, while others present expansion due to tension release after the impression removal.

\section{Conclusion}

The results found in the present study led to the conclusion that different impression materials and techniques influenced the stone cast accuracy in a way that polyether, polysulfide and addition silicone (following the single-phase technique) were more accurate than the other materials.

nyl siloxane impression materials: results from the prosthetic "SuperStudy" - a consumer evaluation. Compend Contin Educ Dent Suppl. 1999;(24):S3-21.

5. Nam J, Raigrodski AJ, Townsend J, Lepe X, Mancl LA. Assessment of preference of mixing techniques and duration of mixing and tray loading for two viscosities of vinyl polysiloxane material. J Prosthet Dent. 2007;97(1):12-7.

6. Johnson GH. Impression materials. In: Craig RG, Powers JM. Restorative dental materials. $11^{\text {th }}$ ed. St Louis: Elsevier; 2001. p. 348-68.

7. Shen C. Materiais de Moldagem. In: Anusavice KJ. Phillips Materiais Dentários. 11 a ed. Rio de Janeiro: Elsevier; 2005. p. 193-237. 
8. Nunes RS, Sinhoreti MAC, Consani S, Sobrinho LC, Goes MF. Avaliação da deformação permanente de materiais de moldagem elastoméricos e alginatos. Pós-Grad Rev Fac Odontol São José dos Campos. 1999;2(1):16-20.

9. Chen SY, Liang WM, Chen FN. Factors affecting the accuracy of elastomeric impression materials. J Dent. 2004;32(8):6039.

10. American Dental Association specification n.11 for dental agar impression material. Chicago: American Dental Association; 1967. p. 81-4.

11. ANSI/ADA specification n.19. Non-aqueous elastomeric dental impression materials. Chicago: American Dental Association; 1982. p. 158-66.

12. Federick DR, Caputo A. Comparing the accuracy of reversible hydrocolloid and elastomeric impression materials. J Am Dent Assoc. 1997;128(2):183-8.

13. Lin CC, Ziebert GJ, Donegan SJ, Dhuru VB. Accuracy of impression materials for complete arch fixed partial dentures. J Prosthet Dent. 1988;59(3):288-91.
14. Peutzfeldt A, Asmussen E. Accuracy of alginate and elastomeric impression materials. Scand J Dent Res. 1989;97(4):3759.

15. Eames WB, Sieweke JC, Wallace SW, Rogers LB. Elastomeric impression materials: effect of bulk on accuracy. J Prosthet Dent. 1979;41(3):304-7.

16. Inoue K, Wilson HJ. Viscoelastic properties of elastomeric impression materials. J Oral Rehabil. 1978;5(4):323-7.

17. Henry PJ, Harnist DJR. Dimensional stability and accuracy of rubber impression materials. Aust Dent J. 1974;19(3):1626.

18. Wee AG. Comparison of impression materials for direct multiimplant impressions. J Prosthet Dent. 2000;83(3):323-31.

19. Chee WW, Donovan TE. Polyvinyl siloxane impression materials: a review of properties and techniques. J Prosthet Dent. 1992;68(5):728-32.

20. Hung SH, Purk JH, Tira DE, Eick JD. Accuracy of one-step versus two-step putty wash addition silicone impression technique. J Prosthet Dent. 1992;67(5):583-9. 